\title{
Firm Value and Entity Choice in Closely Held Business Organizations: Do Taxes Play a Role?
}

\author{
John Cooper \\ California State University Los Angeles
}

\begin{abstract}
This paper examines the role of tax on firm value of closely held businesses. Using sales transactions of closely held business organizations as a proxy for firm value, the double tax system applicable to $C$ corporations versus the single level of tax on passthrough businesses is expected to result in lower firm value for passthrough entities than comparable C corporations. This theoretical assumption is based on increased pricing flexibility available for firms facing a single level of tax over that of entities subject to double taxation. A dataset of nearly 30,000 closely held business sales was evaluated to find that passthrough entities are associated with lower firm value than comparable C corporations. This finding is important since prior research has produced conflicting results. This study contributes to the literature by examining a more comprehensive dataset, including all forms of passthrough entities, and improving the methodology used in earlier studies.
\end{abstract}

Keywords: firm value, passthrough, closely held, market participant, economic surplus, entity choice

\section{INTRODUCTION}

Prior literature has established that entity choice of a closely held business affects the business organization's value. However, extant literature provides conflicting evidence in terms of firm value of C corporations as compared to passthrough entities (Covrig and McConaughy 2015, DiGabriele 2008). This study makes an important contribution to the research on closely held business organizations by examining a more comprehensive dataset, including a broader range of passthrough entities, and employing a more comprehensive methodology. Using actual sales prices of closely held businesses as a proxy for firm value, evidence indicates that passthrough entities are associated with lower firm value than comparable $\mathrm{C}$ corporations, even after controlling for other firm and non-firm characteristics. However, this $\mathrm{C}$ corporation premium varies inversely with size, as measured by annual sales, of the business organization.

The passthrough entity versus $\mathrm{C}$ corporation results of this study are theoretically based on taxation factors inherent in the business sale transaction. On sale of a privately held business, value is allocated among three interested parties: the seller, the buyer, and the government in the form of taxes. How this value is appropriated depends crucially on a decision made much earlier; the legal entity choice made on formation of the business. Entity selection plays a key role because, unlike $\mathrm{C}$ corporations, passthrough entities avoid double taxation, allowing additional value to be appropriated by the buyer or seller rather than the government. Measuring the differences in pricing of comparable $\mathrm{C}$ corporations versus passthrough entities could lead to no significant findings due to such factors as superior negotiation skills of one party 
or exogenous motivations of one or both of the parties to the transaction. Accordingly, the findings of this study likely understate the influence of entity choice on firm value.

A dataset containing information on 29,163 sales of closely held businesses between January 1, 1990 and December 31, 2017, is used to evaluate the roles of entity choice and market participant type on firm value. Based on prior literature, the actual sales price of the business organization serves as a proxy for firm value (Erickson and Wang 2007; Dhaliwal, Erickson, and Heitzman 2004; Granata and Chirico 2010). The dataset, DealStats (formerly known as Pratt's Stats), is populated by information from the Securities and Exchange Commission, merger and acquisition advisors and brokers, and other intermediaries. DealStats provides the date of sale, entity type, sales price, market participant in terms of buyer type (public versus privately held), and transaction type (stock versus asset) for each business sale transaction.

A secondary research question of this paper is to evaluate the influence of market participant type (public or privately held) on firm value of closely held businesses. Prior research has provided inconclusive and, in some cases, conflicting results with respect to this question (Covrig and McConaughy 2015, DiGabriele 2008). This paper provides additional evidence of the role of a public versus a privately held market participant on firm value. Results indicate that a public firm market participant is associated with higher firm value than a privately held market participant.

The findings of this paper make several important contributions to the literature. First, this study uses a comprehensive dataset to resolve differing results in the prior literature regarding the influence of entity type on firm value while controlling for other firm and non-firm characteristics. Second, while extant research is generally limited to $\mathrm{C}$ versus $\mathrm{S}$ corporation analyses, this paper extends the analysis to $\mathrm{C}$ corporations versus all types of passthrough entities. Inclusion of all passthrough entity types is important because all passthrough entities share similar tax attributes that are the focus of this study. Third, the results add to our understanding of the implications of the market participant on firm value which is currently unclear. And, finally, the findings have practical implications for business owners, consultants, and researchers interested in closely held businesses.

The remainder of this paper is structured as follows. The next section discusses the background of entity choice and market participant type. Following that is a review of the literature addressing the influence of income tax considerations of entity choice and market participant type on firm value. A discussion of theory and hypotheses development follows. After that is a description of the dataset, and a discussion of the research methodology and results. Finally, implications of this study and possible future research directions are provided.

\section{BACKGROUND}

Selection of entity form is one of the many choices made at inception of a business organization. An extensive literature has explored the considerations that are involved in choices made on formation of the business (Dyer and Ross 2007, Blair and Marcum 2015). Business owners typically make the entity selection decision based on considerations of six factors: risk potential of the business, number of owners, start-up costs, complexity of paperwork, sophistication of the small business owner, and the existence of appreciating assets (Blair and Marcum 2015). Accordingly, taxation and firm value considerations receive little if any attention in this process although the decision may carry real and lasting value implications.

The most common entity choices include the sole proprietorship, partnership, Limited Liability Company, S corporation, and C corporation (Blair, Marcum, and Fry 2009). Each of these entity choices brings with it both favorable and unfavorable consequences, but a clear distinction exists between the $\mathrm{C}$ corporation and the other entities (Blair and Marcum 2015). Operating as a $\mathrm{C}$ corporation has the inherent disadvantage of double taxation. Double taxation refers to a situation in which income tax is paid twice on the same income, once at the corporate level and again when that income is distributed to the entity owners

(DeCelles and Wichmann 1986). In contrast, passthrough entities, which include S corporations, Limited Liability Companies, partnerships, and sole proprietorships, avoid this double tax penalty through application of the "conduit" approach wherein income is taxed only once at the owner level (DeChellis, Young, Van Grevenhof, and Groat 2017). 
Unlike publicly traded corporations, where ownership transfer is typically accomplished through the sale of stock, ownership transfer in a privately held company is often structured as an asset sale of all the tangible and intangible assets of the business. This acquisition structure allows the buyer a legal "fresh start" since the acquired business assets are transferred to a new business entity at, generally, fair market value. Therefore, the buyer in an asset sale receives tax benefits associated with higher future depreciation and amortization deductions. An asset sale of a business organization structured as a $\mathrm{C}$ corporation generally results in double taxation to the seller; tax on sale of the assets inside the corporation and then tax on distribution of the sale proceeds to the shareholders. In contrast, an asset sale of a passthrough entity results in only a single level of tax at the owner level. Thus, the seller of a passthrough entity realizes a tax savings when compared to an asset sale of a business operated as a $\mathrm{C}$ corporation. This reduced tax burden represents an economic surplus that is available to be appropriated by either the buyer, the seller, or a combination of both.

The economic surplus attributable to selection of a passthrough entity can be substantial. Prior to January 1, 2018, tax rates for $\mathrm{C}$ corporations topped out at 35\% while maximum individual tax rates were $20 \%$ for qualifying dividends and capital gains, and $39.6 \%$ for ordinary income. Assuming the best case where all income paid to the shareholders was taxed at preferential capital gain rates, the effective tax on an asset sale of a C corporation was $48 \%(35 \%+(65 \% \times 20 \%))$. The worst case for an asset sale of a passthrough entity was $39.6 \%$, representing just over an $8 \%$ advantage for the passthrough entity structure. However, in most cases some part of the gain for the passthrough owner would be taxed at preferential capital gains rates $(20 \%)$, substantially increasing the tax benefit associated with passthrough entities on sale of assets.

Transactions not structured as an asset sale are made by selling the owner's interest in the entity. In the case of a C or S corporation, ownership is represented by shares of stock. For partnerships and limited liability companies, ownership is represented by either a partnership interest or a member interest. Sole proprietorships cannot be sold other than in an asset sale and are, therefore, not considered in the discussion of sale of an ownership interest. C corporations also differ from these passthrough entities in that the passthrough owner's tax basis in the entity is adjusted annually for income, deductions, contributions, and distributions. Accordingly, while the tax basis in a C corporation owner's stock is generally what was paid for it, the tax basis in the passthrough entity adjusts each year. This characteristic has the potential to affect firm value, even in sales of ownership interests, by reducing the tax due on sale of the business for a passthrough entity as compared to a $\mathrm{C}$ corporation.

Whether the business organization sale is structured as an asset sale or a sale of the owner's interest, continuity of the selected entity type is assumed in this study. This assumption is well-founded because once the entity choice has been made, changing to another form generally carries a substantial cost. Converting from a $\mathrm{C}$ corporation to a passthrough entity is penalized through a tax on appreciated tangible and intangible property held by the organization (IRC $\S$ 1374(a)). Accordingly, changing from a C corporation to another entity form is generally a rational choice only in very limited situations. Alternatively, changing from a passthrough entity to a $\mathrm{C}$ corporation brings the double taxation penalty on sale making this an unlikely choice of any owner of a closely held business.

\section{LITERATURE REVIEW}

\section{Effect of Income Tax on Firm Value}

The influence of income tax on firm value has frequently been examined in the literature (Desai and Dharmapala 2009; Cloyd, Mills, and Weaver 2003; Swenson 1999). The relationship is anchored in two theories: the traditional theory and the theory of agency (Ilaboya, Izevbekhai, and Ohiokha 2016). The traditional theory posits that firm value is positively related to cash flows and that lower taxes result in higher cash flows leading to higher firm value. Agency theory rests on the assumption that tax planning can be complex and vague, and this can result in managerial opportunism. Agency theory suggests that tax planning leads to lower firm value as managers understate firm profits and taxable income (Desai and 
Dharmapala 2009). Although extant literature has failed to resolve these competing theories, researchers have established that income tax is value relevant.

Erickson and Wang (2000) provided evidence that a favorable tax structure in an acquisition positively affects the target value. Using a sample of sales of subsidiary businesses from the Securities Data Company Mergers and Acquisitions Database, the authors found a significant relationship between tax structure of the transaction and sales price of the target business. Specifically, tax benefits generated by an I.R.C. $\S$ 338(h)(10) election were found to be positively associated with target pricing. The I.R.C. $\S 338(\mathrm{~h})(10)$ election provides a tax benefit to the acquiring firm in the form of increased depreciation and amortization deductions by recharacterizing a stock purchase as an asset purchase. This tax election allows the acquiring firm a "fresh start" on depreciation of the acquired assets and creates increased tax basis for acquired intangibles, producing a favorable tax benefit for the buyer. The tax implications related to recharacterization of the transaction through this tax election were found to affect pricing: transactions where the I.R.C. $\S 338(\mathrm{~h})(10)$ election was made yielded higher sale prices than acquisitions where no election was made. Accordingly, the study suggested the existence of an S corporation valuation premium although the findings were, in fact, based on the implications of the I.R.C. $\S 338(\mathrm{~h})(10)$ election.

The influence of tax optimization on firm value was evaluated by Assidi, Aliani, and Omri (2016). Tax optimization consists of steps management takes to reduce the firm's tax burden resulting in increased cash flows. Tunisian firms operating over an eleven-year period were analyzed to find that tax optimization was negatively associated with firm value. Thirty-five firms providing 385 firm-year observations served as the study sample data. The study used return on assets as a proxy for firm value with effective tax rate, debt, accruals, firm size, and auditor type as control variables. The study provided evidence favoring agency theory by finding that tax savings were associated with reduced firm value.

Bryant-Kutcher, Guenther, and Jackson (2012) found evidence supporting the traditional theory by evaluating business organizations operating in foreign jurisdictions with lower tax rates. The study results showed that lower tax rates were associated with increased firm value. The study reviewed 1,475 U.S. publicly traded multinational firms using Tobin's q as a proxy for firm value. Foreign operations in low effective tax rate jurisdictions were evaluated and found to increase firm value as measured by Tobin's q.

In contrast, Demere and Gramlich (2018) reported an inverse relationship between firm value and tax savings. For each $1 \%$ increase in tax savings there was a $.5 \%$ reduction in firm value. This research examined tax-motivated income shifting and included consideration of investor analyst oversight. The study involved 22,467 firm-year observations of publicly traded companies reported on Compustat. Tobin's q was used as a proxy for firm value with foreign operations in low effective tax rate jurisdiction weighted by percent of foreign operations as a control variable. This study provided evidence in support of the agency theory.

An extensive literature review examined the relationship between tax planning and firm value (Ilaboya, Izevbekhai, and Ohiokha 2016). Evidence supporting both agency theory and the traditional theory continues to be supported in the literature leading the authors to comment, "The major challenge in our opinion is the inconsistency in research findings on the relationship between tax planning and firm value." While the direction of the influence of tax on firm value has yet to be resolved, it is clear that taxation does play a role in firm value.

\section{Target Entity and Firm Value}

Research has addressed the relationship between characteristics of the target entity and firm value finding that firm-specific features do affect firm value. For example, Granata and Chirico (2010) considered the influence of family owned target business organizations on acquisition pricing. The study involved matched pairs of publicly traded and family owned and operated food and drink industry businesses located in Europe. The actual sales price of these businesses was used as a proxy for firm value. The study established that, despite superior performance of family firm targets in some cases, acquiring firms routinely discounted pricing of family owned and operated firms based on the perception that these firms were more inefficient and unprofessional than non-family firms. 
Seller tax liability has also been shown to affect firm value. Dhaliwal, Erickson, and Heitzman (2004) used taxable versus nontaxable sales of hospitals to demonstrate that sellers with higher tax liabilities attributable to the sale demand higher sales prices for the business. The positive association of taxes to firm pricing was theorized to be attributable to the lock-in effect which posits that sellers are more resistant to sales price reductions as the tax on sale increases. The relationship was further tested in a study of crosstemporal differences in capital gains tax rates on the sales price of businesses (Ayers, Lefanowicz, and Robinson 2003). This longitudinal study examined 935 public company acquisitions which spanned five different long-term capital gains rate regimes with 565 taxable cash-for-stock acquisitions and 370 tax-free stock-for-stock transactions. The study supported the lock-in affect in that higher capital gains taxes were associated with higher transaction prices.

Evidence that the organizational structure of the target influences sales price of the business was found in a study involving 77 matched pairs of privately held C and S corporations (Erickson and Wang 2007). The study involved stock purchases of $\mathrm{C}$ and $\mathrm{S}$ corporations announced between January 1, 1994, and December 31, 2000. All S corporation acquisitions included an I.R.C. § 338(h)(10) election, effectively converting the transaction to an asset purchase for tax purposes. Industry matched $\mathrm{C}$ corporation sales were paired with each S corporation sale to evaluate the effect of target organizational structure on pricing. The study found that $\mathrm{C}$ corporations were unlikely to make the I.R.C. $\S 338(\mathrm{~h})(10)$ election due to the implications of double taxation. As a result, stock sales of S corporations where the tax election was made were compared to stock sales of $\mathrm{C}$ corporations. The study provided evidence that the benefits of the I.R.C. $\S 338(\mathrm{~h})(10)$ election increased target firm value over acquisitions where no election was made. However, while sales of comparable $\mathrm{C}$ and $\mathrm{S}$ corporations were used in this study, the I.R.C. $\S 338(\mathrm{~h})(10)$ election that was made by the $\mathrm{S}$ corporations resulted in comparing stock sales of $\mathrm{C}$ corporations with asset sales of $\mathrm{S}$ corporations. As a result, this study shed little light on entity choice as an influence on firm value.

Two studies used that used the same database as this analysis produced conflicting results. DiGabriele (2008) conducted a moderated multiple regression analysis on sales of $\mathrm{C}$ and $\mathrm{S}$ corporations using a sample of 4,239 sales consisting of 2,159 C corporations and 2,080 S corporations. In this study, DiGabriele found evidence of an $\mathrm{S}$ corporation premium over $\mathrm{C}$ corporation pricing. The premium was moderated by transaction type, buyer type, and several two-way interaction variables. Additionally, the premium was found to be higher for transactions structured as asset sales over those structured as stock sales. However, several conditions of this study leave unanswered questions: First, the study was limited to $\mathrm{C}$ and $\mathrm{S}$ corporations and ignored all other passthrough entity types. Second, the study did not include any control variables. Considering the study covered sales of these business organizations from 1990 through early 2007, many exogenous factors could be influential. For example, economic upturns or downturns, changes in unemployment rates, and even the industry of the target business could all affect results.

The second study was conducted by Covrig and McConaughy (2015). This analysis found conflicting results with the DiGabriele analysis in that it provided evidence that $\mathrm{C}$ corporations sell at higher prices than comparable S corporations. The study used the same database as DiGabriele and also limited the analysis to only $\mathrm{C}$ and $\mathrm{S}$ corporations; however, this study examined a different period of time and limited the sample to businesses that had at least \$1 million in annual sales. The resulting dataset included 4,192 transactions from 2000 through 2011. In contrast to DiGabriele, where the dependent variable was the natural $\log$ of the sales price of the business, Covrig and McConaughy (2015) used valuation ratios such as the market value of invested capital divided by annual sales or, alternatively, divided by EBITDA, as a proxy for firm value. Certain industries classified under SIC 6 were excluded from the study. These excluded industries were companies primarily involved in finance, insurance, and real estate. The Covrig and McConaughy study included fixed effects control variables for year and industry and also controlled for age of the business and gross profit margin.

Both the DiGariele (2008) and Covrig and McConaughy (2015) studies used Pratt's Stats, now called DealStats, as the data source, yet found conflicting results. DiGabriele found S corporations sell at higher prices than comparable $\mathrm{C}$ corporations while the Covrig and McConaughy study produced results suggesting $\mathrm{C}$ corporations sell at higher prices relative to comparable $\mathrm{S}$ corporations. A primary 
contribution of this paper is to re-evaluate these conflicting results in furtherance of our understanding of non-publicly traded business organizations.

\section{Market Participant and Firm Value}

Market participant as an influence on firm value has also been the subject of researchers; however, less attention has been paid to this issue. Bargeron, Schlingemann, Stulz, and Zutter (2008) studied pricing difference in business acquisitions based on public versus private market participants. The study involved a sample of acquisitions from the Securities Data Company's U.S. Merger and Acquisition Database. All completed majority acquisitions between 1980 and 2005 between U.S. public targets and U.S. market participants were included. Non-operating company acquisitions and those labeled as spin-off, recapitalizations, or privatizations were excluded. After other restrictions on the sample, 1,667 transactions were examined. Of these, 453 involved a private market participant and 1,214 were public market participants. The study found that public market participants, on average, provided a $35 \%$ premium to target shareholders on acquisition.

DiGabriele (2008) and Covrig and McConaughy (2015), discussed above, also examined the role of market participant type on firm value and again found conflicting results. DiGabriele reported that privately held market participants are associated with pricing premiums over that of public company acquirers, regardless of the target entity type. However, Covrig and McConaughy provided evidence supporting a pricing premium associated with public acquirers over private acquirers. Several differences in the studies could, in part, explain the conflicting results. First, the time period of each analysis differed. Second, DiGabriele used the natural log of annual sales as a proxy for firm value while Covrig and McConaughy used valuation ratios. Third, Covrig and McConaughy limited the study to businesses with at least $\$ 1$ million in annual sales. And, finally, while Covrig and McConaughy included several control variables, DiGabriele did not. However, both studies used the same dataset and asked, fundamentally, the same questions: is there a pricing premium associated with $\mathrm{S}$ corporations over comparable $\mathrm{C}$ corporations and is pricing influenced by the market participant type? This conflicting evidence presents a challenge for researchers interested in understanding closely held business organizations.

\section{THEORY AND HYPOTHESES DEVELOPMENT}

Extant literature establishes a relationship between target organizational structure and firm value. However, based on prior research, the implications of the relationship are still unclear and require further evaluation. It is also been shown that market participant type, public or private, is associated with the firm value of closely held business organizations. However, based on existing research the relationship of this factor on firm value is also unclear. A fundamental contribution of this paper is to provide additional evidence regarding the influence of entity choice and market participant type on firm value.

Firms involved in acquisition of privately held business organizations engage in a thorough due diligence review of the target business. During this process, the acquiring firm develops an in-depth understanding of the target firm; its market position, innovative characteristics, staffing, income tax history, and entity form. Information reviewed on the target income tax returns allows the acquirer to estimate taxable gain on sale based on the expected transaction price and the target entity form. This information provides the acquirer with an estimate of the tax burden faced by the target - double tax if the target is a $\mathrm{C}$ corporation or a single level of tax if the target is a passthrough entity. Acquiring firms recognize the existence of an economic surplus when the target is a passthrough and are theorized to take this into account through a downward adjustment to transaction pricing. This reduction in pricing is an attempt to appropriate part of the economic surplus available from the tax savings associated with passthrough entity targets.

The target business organization is also aware of the existence of an economic surplus when the business is formed as a passthrough and is expected to be more flexible in pricing than if it were a $\mathrm{C}$ corporation subject to a double tax on sale. Accordingly, the passthrough target has more flexibility in pricing. 
Another characteristic of passthrough entities has the potential to reduce taxable gain on sale. Unlike C corporations, the owner's tax basis in the passthrough entity is adjusted annually for increased investment in the business. This increased investment can be in the form of additional cash or property contributions, or in the form of taxable income that is left in the business. In either case, these additions to tax basis of the ownership interest reduce the taxable gain on sale and, thus, gives the passthrough entities an advantage over comparable $\mathrm{C}$ corporation organizations. This leads to the following hypothesis:

\section{H1: Passthrough entities will be associated with lower firm value than comparable C corporations.}

Characteristics of the market participant, particularly whether the acquirer is privately held or publicly traded, are also theorized to affect firm value. Although there is disagreement in the literature regarding the direction of the relationship, there are several possible theoretical considerations. A public firm is likely to have access to capital not available to a privately held firm, the public firm is in a position to access superior negotiators for the transaction, and the public firm has a formal board of directors to oversee and approve proposed acquisitions (Slee 2005). In addition, the privately held target firm may view interest from a public company as a stronger marker of success than interest from a privately held firm and holdout for a higher price. Although some of these considerations favor a negative relationship between pricing and public market participants, it is expected that the public market participant will be associated with higher pricing for comparable target businesses. In part, the public market participant is in a position to cherry pick targets in specific industries with synergistic compatibilities along with superior access to capital. Therefore, it is expected that a publicly traded market participant will be associated with increased firm value.

H2: Firm value will be higher when the market participant is publicly traded than when it is privately held.

\section{DATA AND DESCRIPTIVE STATISTICS}

This study uses a comprehensive dataset of closely held business sales between January 1, 1990 and December 31, 2017, to evaluate the influence of entity choice and market participant type on firm value. The dataset, DealStats, provides information on 29,163 sale transactions during this period of time. Transactions occurring after December 31, 2017 were eliminated to minimize the effect of the 2017 Tax Cuts and Jobs Act which made sweeping changes to the tax rates of both $\mathrm{C}$ corporations and passthrough business organizations. Other eliminations in the data included non-U.S. targets, non-profit organizations, and transactions with missing target type, transaction type, or sales. After eliminations, the sample set was comprised of 25,026 transactions (Table 2). Variable definitions are provided in Table 1.

TABLE 1

\section{VARIABLE DEFINITIONS}

\begin{tabular}{cl}
\hline Firm Value Variables & \\
\hline Ln_FirmVal & The natural log of the sale price of the business \\
Ln_Sales & Annual sales of target business transformed to natural log \\
CCorp & Indicator variable where C corporation $=1$ and passthrough entities $=0$ \\
Public & Indicator variable where public acquirer $=1$ and private acquirer $=0$ \\
StockSale & Indicator variable where stock sale $=1$ and asset sale $=0$ \\
\hline Control Variables & \\
Unemp & Change in national unemployment rate by year \\
Ind & Industry of target business organization \\
GDP & Change in gross domestic product by month and year \\
Year & Year of sale \\
\hline
\end{tabular}


TABLE 2

\section{SAMPLE SELECTION}

\begin{tabular}{lr}
\hline Sale Transactions in DealStats from 1990 through March 31, 2018 & 29,163 \\
Remove Non-U.S. Targets & $(1,928)$ \\
Remove Ltd. and Consolidated targets & $(594)$ \\
Remove Non-Profits & $(8)$ \\
Require Transaction Type (Stock v. Asset) & $(4)$ \\
Require Target Type & $(1,443)$ \\
Require Transaction Sales Price & $(1)$ \\
Require Annual Sales & $(127)$ \\
Require U.S. Currency Transaction & $(32)$ \\
$\quad$ Final Sample & 25,026 \\
\hline
\end{tabular}

This table presents the sample selection procedure followed in the study.

Table 3 provides the transaction frequency by year. The database began tracking business organization sales information in 1990 and, as a result, had very few transactions listed during 1990 through 1995. The impact of U.S. recessions in early 2001 and 2009 resulted in reductions in the number of transactions. However, Table 3 clearly shows strong representation of business sales over an extended period of time.

TABLE 3

TRANSACTION FREQUENCY BY YEAR

\begin{tabular}{ccrr}
\hline Sale Year & Frequency & Percent & Cumulative \\
1990 & 3 & $0.0 \%$ & $0.0 \%$ \\
1991 & 3 & $0.0 \%$ & $0.0 \%$ \\
1992 & 7 & $0.0 \%$ & $0.1 \%$ \\
1993 & 16 & $0.1 \%$ & $0.1 \%$ \\
1994 & 43 & $0.2 \%$ & $0.3 \%$ \\
1995 & 125 & $0.5 \%$ & $0.8 \%$ \\
1996 & 401 & $1.6 \%$ & $2.4 \%$ \\
1997 & 582 & $2.3 \%$ & $4.7 \%$ \\
1998 & 926 & $3.7 \%$ & $8.4 \%$ \\
1999 & 984 & $3.9 \%$ & $12.3 \%$ \\
2000 & 925 & $3.7 \%$ & $16.0 \%$ \\
2001 & 821 & $3.3 \%$ & $19.3 \%$ \\
2002 & 878 & $3.5 \%$ & $22.8 \%$ \\
2003 & 859 & $3.4 \%$ & $26.3 \%$ \\
2004 & 1,220 & $4.9 \%$ & $31.1 \%$ \\
2005 & 1,306 & $5.2 \%$ & $36.4 \%$ \\
2006 & 1,264 & $5.1 \%$ & $41.4 \%$ \\
2007 & 1,388 & $5.5 \%$ & $47.0 \%$ \\
2008 & 1,468 & $5.9 \%$ & $52.8 \%$ \\
2009 & 946 & $3.8 \%$ & $56.6 \%$ \\
\hline
\end{tabular}




\begin{tabular}{rrrr}
\hline 2010 & 1,164 & $4.7 \%$ & $61.3 \%$ \\
2011 & 1,139 & $4.6 \%$ & $65.8 \%$ \\
2012 & 1,171 & $4.7 \%$ & $70.5 \%$ \\
2013 & 1,276 & $5.1 \%$ & $75.6 \%$ \\
2014 & 1,551 & $6.2 \%$ & $81.8 \%$ \\
2015 & 1,548 & $6.2 \%$ & $88.0 \%$ \\
2016 & 1,685 & $6.7 \%$ & $94.7 \%$ \\
2017 & 1,327 & $5.3 \%$ & $100.0 \%$ \\
\hline Total & 25,026 & & \\
\hline
\end{tabular}

The dataset includes a range of industries as shown in Table 4. Transactions were classified into twelve industry segments based on the Fama-French (1997) model. A review of industry classification by entity type shows heavy concentrations in Wholesale/Retail and in "Other" for both $\mathrm{C}$ corporations and passthrough entities. The industry category labelled "Other" includes Construction, Entertainment, Transportation, and Business Services. As shown in Table 4, the data provides a good representation across all industry classifications and strong representation of both $\mathrm{C}$ corporation and passthrough entities within each industry class.

Table 5 provides a count of all transactions included in the analysis. Transaction data is parsed into several categories: passthrough/C corporations, asset/stock sale, and public/private market participant. This table shows that acquisition of a closely held business is predominantly characterized as an asset purchase of a passthrough entity made by a privately held market participant. The predominance of asset purchases reflects the market participant's objective of obtaining increased tax basis in the acquired business organization to produce higher depreciation and amortization deductions. Table 5 also shows that privately held businesses in the dataset operate as passthrough entities nearly three times as often as $\mathrm{C}$ corporations, suggesting a motivation to avoid the double tax regime of $\mathrm{C}$ corporations. The data also shows that market participants are more likely to be privately held - approximately $77 \%$ of the market participants are private. Overall, this stratification of the data provides interesting and useful information for those interested in closely held businesses.

TABLE 4

TARGET STRUCTURE BY INDUSTRY

\begin{tabular}{|c|c|c|c|c|}
\hline & Pass-Through & C corporation & Total & Percent \\
\hline Non-Durables & 1,083 & 297 & 1,380 & $5.5 \%$ \\
\hline Durables & 311 & 139 & 450 & $1.8 \%$ \\
\hline Manufacturing & 920 & 565 & 1,485 & $5.9 \%$ \\
\hline Energy & 59 & 67 & 126 & $0.5 \%$ \\
\hline Chemicals & 62 & 63 & 125 & $0.5 \%$ \\
\hline Business Equipment & 655 & 1,196 & 1,851 & $7.4 \%$ \\
\hline Telecommunications & 120 & 155 & 275 & $1.1 \%$ \\
\hline Utilities & 29 & 18 & 47 & $0.2 \%$ \\
\hline Whlse/Retail Shops & 8,319 & 1,680 & 9,999 & $40.0 \%$ \\
\hline Health & 838 & 570 & 1,408 & $5.6 \%$ \\
\hline Money & 568 & 400 & 968 & $3.9 \%$ \\
\hline Other & 5,379 & 1,533 & 6,912 & $27.6 \%$ \\
\hline Total & 18,343 & 6,683 & 25,026 & $100.0 \%$ \\
\hline
\end{tabular}

This table provides information regarding industry of the target entity by entity type: Passthrough or $\mathrm{C}$ corporation. "Other" includes transportation, entertainment, construction and business services. Industry categories are based on the Fama-French (1997) model. 
Review of the data indicated only one IRC $\S 338(\mathrm{~h})(10)$ election made by an S corporation. No IRC $\S$ 338(h)(10) elections were made by $\mathrm{C}$ corporations. As discussed earlier, the IRC $\S 338(\mathrm{~h})(10)$ election treats a stock purchase as an asset purchase for tax purposes. This observation was treated as an asset sale in the analysis.

An IRC $\S 368$ reorganization could also affect results of this study. IRC $\S 368$ provides an opportunity for corporations to engage in tax free reorganizations such as mergers and acquisitions. If all requirements are met, the parties to the transaction avoid tax implications on the transaction. Only $2 \mathrm{~S}$ corporations and $18 \mathrm{C}$ corporations were involved in IRC $\S 368$ corporate reorganizations in the dataset; however, after review, the pricing information of these transactions was still relevant for purposes of this analysis. Accordingly, these transactions were included in the analysis without revision.

Descriptive statistics for the variables of interest are presented in Table 6. Both Firm Value and Sales exhibited large, positive skew and kurtosis due to a small number of very high amounts. To correct for this, the data for these variables were transformed to natural logarithms. The resulting data still exhibited problematic skewness necessitating further adjustment. Accordingly, the data was Winsorized (Yale and Forsythe 1976) which reduced the skewness and kurtosis to acceptable levels. The Winsorized values for skewness were .6057 and .4966 for Firm Value and Sales, respectively. Kurtosis was 1.9571 for Firm Value and 1.9129 for Sales. After these adjustments, kurtosis and skewness were indicative of approximate normality. Results of this analysis are qualitatively similar to what was produced from the pre-Winsorized data. Table 6 presents the mean, standard deviation, and $\min / \mathrm{max}$ of each of the variables of interest.

\section{TABLE 5}

\section{TRANSACTION COUNT DETAIL}

\begin{tabular}{|c|c|c|c|}
\hline \multirow[b]{3}{*}{ Passthrough: } & \multicolumn{2}{|c|}{ Acquirer Type } & \multirow[b]{2}{*}{ Total } \\
\hline & \multirow{2}{*}{ Public } & \multirow[t]{2}{*}{ Private } & \\
\hline & & & \\
\hline Asset & 906 & 15,615 & 16,521 \\
\hline Stock & 1,302 & 520 & 1,822 \\
\hline Subtotal & 2,208 & 16,135 & 18,343 \\
\hline \multicolumn{4}{|c|}{ C corporation: } \\
\hline Asset & 997 & 2725 & 3,722 \\
\hline Stock & 2547 & 414 & 2,961 \\
\hline Subtotal & 3,544 & 3,139 & 6,683 \\
\hline Total Asset & 1,903 & 18,340 & 20,243 \\
\hline Total Stock & 3,849 & 934 & 4,783 \\
\hline Total All & 5,752 & 19,274 & 25,026 \\
\hline
\end{tabular}


TABLE 6

DESCRIPTIVE STATISTICS

\begin{tabular}{|c|c|c|c|c|}
\hline & Mean & Std. Dev. & Min & Max \\
\hline Ln_FirmVal & 13.228 & 1.729 & 11.290 & 16.180 \\
\hline Ln_Sales & 13.795 & 1.414 & 12.104 & 16.188 \\
\hline CCorp & 0.267 & 0.442 & 0 & 1 \\
\hline Public & 0.230 & 0.421 & 0 & 1 \\
\hline StockSale & 0.191 & 0.393 & 0 & 1 \\
\hline
\end{tabular}

This table presents descriptive statistics for the variables employed in the study. Refer to Table 1 for variable definitions.

\section{RESEARCH DESIGN AND RESULTS}

Table 7 presents the results of a linear regression analysis used to estimate the influence of entity choice and market participant type on firm value. Three groups were evaluated: First, all transactions, which includes both stock sales and asset sales (Models (1) and (2)). Second, transactions structured as stock sales (Models (3) and (4)). And, finally, transactions structured as a sale of the assets of the business (Models (5) and (6)). For each pairing, the natural log of firm value is regressed on entity type, transaction type, buyer type and the natural log of sales.

The dependent variable, Ln_FirmVal, is the natural log of the sales price of the transaction. As discussed above, the sales price of the business has been used as a proxy for firm value in prior research (DiGabriele 2008; Bargeron, Schlingemann, Stulz, and Zutter 2008). The primary variable of interest (CCorp) is a dummy variable representing the entity type of the business, $\mathrm{C}$ corporation or passthrough entity, with passthrough entity as the reference category taking a value of zero and C corporations taking a value of one. The secondary variable of interest is market participant type (Public). This categorical variable assigns privately held market participants as the reference category with publicly traded market participants taking a value of one. The transaction type is represented by StockSale, which uses asset sales as the reference category and stock sales as a 1.

Several important control variables are also included. Annual sales (Ln_Sales) control for the size of the business. Year of sale is an important control variable because firm value may be changing due to unobserved time trends. Industry classification relies on the Fama French model of twelve industry categories (Fama and French 1997) and is necessary to account for industry differences. The year of the transaction and industry of the target are included in the regression as fixed effects. Other control variables include the change in unemployment rate and gross domestic product, important indicators of economic conditions that could influence transaction pricing.

The regression takes the following form:

$$
\begin{aligned}
& \text { Ln_FirmVal }_{\text {iy }}=\beta_{0}+\beta_{1} \text { CCorp }_{\text {iy }}+\beta_{2} \text { Public }_{\text {iy }}+\beta_{3} \text { StockSale }_{\mathrm{iy}}+\beta_{4} \text { Ln_Sales }_{\mathrm{iy}}+\beta_{5} \text { Unemp }_{y} \\
& \quad+\beta_{6} G D P_{y}+\delta_{\mathrm{i}}+\eta_{\mathrm{y}}+\epsilon_{\mathrm{iy}}
\end{aligned}
$$

In Equation (1), $i$ represents the industry of the target business organization and $y$ is year of the sale transaction. Equation (1) was used for models (1), (3), and (5).

Models (2), (4), and (6) include several interaction effects: CCorp x StockSale and StockSale x Public (Model 2 only) and CCorp x Public, CCorp x Ln_Sales, and Public x Ln_Sales (Models (2), (4) and (6)). The interactions are theoretically driven by the assumption that the influence of CCorp and Public and of StockSale and Public will be different at different levels of Ln_Sales, and that the interaction of CCorp with Public may also provide important explanatory information. Inclusion of the interaction effects resulted in increased adjusted $\mathrm{R}^{2}$ amounts indicating these factors moderate the results. 
As shown in Table 7 Models (1) and (3), the main effect of C corporation versus passthrough entity on firm value is positive and statistically significant for All Transactions and for Stock Sales supporting hypothesis H1: C corporations are associated with higher sales pricing than comparable passthroughs. The main effect of market participant type indicates a premium for public buyers in Models (1), (3), and (5) supporting $\mathrm{H} 2$.

Results indicate the very strong influence of market participant type as well as one of the control variables, annual sales (Ln_Sales). Public market participants were theorized to be associated with higher firm value, so this is expected. Annual sales was used as a control variable to represent the size of the business. There is a very strong influence of sales on firm value shown in the data. This is attributable to how these closely held businesses are generally valued. Closely held business organizations are not subject to the stringent accounting rules which guide financial reporting for public companies. As a result, the financial statements produced by these entrepreneurial businesses are not consistently prepared; variations in expense classification and even, in some cases, inclusion of non-business expenses, render net income and even gross profit as unreliable markers for researcher's reliance. However, annual sales are considered more reliable and, as a result, valuators typically use approaches to value that rely on this metric (Pratt, Reilly, and Schweihs 2000).

The interaction effects are shown in Table 7, Models (2), (4), and (6). The interaction of CCorp and StockSale is slightly positive and statistically significant in Model (2), indicating a relatively mild interaction effect between market participant type and stock versus asset sale. This positive interaction suggests higher target pricing with stock sales of C corporations. The interaction of CCorp and Public is positive and highly statistically significant supporting the theory that publicly traded market participants and C corporations are associated with higher firm value. However, the interaction of CCorp with Ln_Sales and Public with Ln_Sales is negative and significant which means as annual sales increase, the premium associated with $\mathrm{C}$ corporation pricing decreases. The same holds true for public market participants: as sales increase the premium associated with publicly traded market participants decreases. In Model (6), the simple effect of CCorp is positive and highly significant supporting H1.

Table 7, Model (2) is viewed as the primary results of this study because it includes all transactions and the influence of important interaction terms. Model (2) shows strong support for a pricing premium associated with businesses operating as $\mathrm{C}$ corporations $(\mathrm{H}$ !), as well as a premium for public market participants $(\mathrm{H} 2)$. The interactions show that the premiums vary inversely with the size of the target business.

TABLE 7

REGRESSION MODELS

\begin{tabular}{|l|ccc|cc|cc|}
\multicolumn{9}{c|}{$\boldsymbol{D}$ D $=$ Ln_FirmVal } \\
\cline { 2 - 7 } \multicolumn{1}{c|}{} & \multicolumn{2}{c|}{ All Transactions } & \multicolumn{2}{c|}{ Stock Sales } & \multicolumn{2}{c|}{ Asset Sales } \\
\cline { 2 - 7 } & $(1)$ & $(2)$ & $(3)$ & $(4)$ & $(5)$ & $(6)$ \\
\hline Constant & $3.0140^{* * *}$ & $1.5755^{* * *}$ & $5.7917^{* * *}$ & $-2.6483^{* * *}$ & $2.3404^{* * *}$ & $1.8793^{* * *}$ \\
& $(0.3852)$ & $(0.3688)$ & $(0.4435)$ & $(0.4699)$ & $(0.3631)$ & $(0.3605)$ \\
& & & & & \\
StockSale & $0.0301^{* *}$ & $1.0971^{* * *}$ & $0.1293^{* * *}$ & $2.5382^{* * *}$ & -0.0183 & $0.6198^{* * *}$ \\
& $(0.0106)$ & $(0.1249)$ & $(0.0229)$ & $(0.2764)$ & $(0.0117)$ & $(0.1484)$ \\
Public & & & & & \\
& $0.2779^{* * *}$ & $0.3360^{* * *}$ & & & & \\
Ln_Sales & $(0.0144)$ & $(0.0246)$ & & & & \\
& $1.0852^{* * *}$ & $7.1123^{* * *}$ & $1.1518^{* * *}$ & $10.4248^{* * *}$ & $1.0562^{* * *}$ & $5.0576^{* * *}$ \\
& $(0.0170)$ & $(0.1522)$ & $(0.0317)$ & $(0.3285)$ & $(0.0204)$ & $(0.2211)$ \\
\hline
\end{tabular}




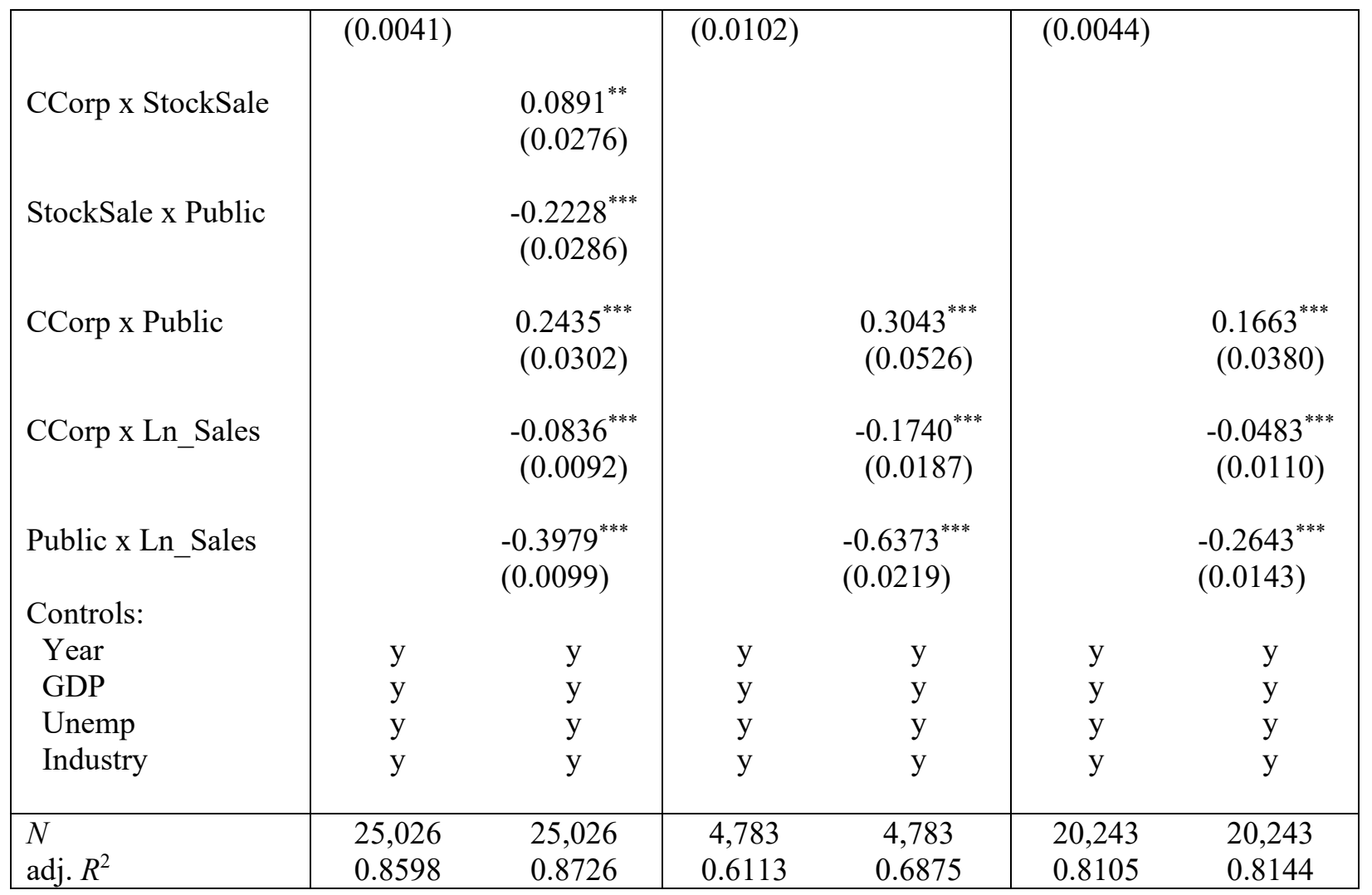

Standard errors in parentheses

${ }^{*} p<0.05,{ }^{* *} p<0.01,{ }^{* * *} p<0.001$

Controls $=\mathrm{y}$ : controls for year, industry, unemployment, and for the change in GDP are included.

Models (1) and (2) regress Firm Value for all transactions including stock and asset sales. Models 3 and 4 regress Firm Value on stock sales. Models 5 and 6 regress Firm Value on asset sales. Interaction effects are included in Models (2), (4), and (6). Ln_Sales eliminated in Models (2), (4), and (6) due to collinearity with interaction terms.

\section{DISCUSSION AND CONCLUDING REMARKS}

The results of this analysis contribute to the underrepresented but growing body of knowledge on the influence of taxation on privately held business organization value. Understanding the implications of entity selection and market participant type on firm value provides useful insight for managers, entrepreneurs, and researchers. This research is also important because entity selection is a foundational choice across many disciplines including finance and accounting.

Results suggest that $\mathrm{C}$ corporations are associated with higher firm value than comparable passthrough entities. The study also provides evidence of a public company market participant premium over that of private company market participants. Interaction effects provide support for the declining influence of entity type and market participant type on firm value as the size of the target, in terms of annual sales, increases.

Several additional research questions arise from this analysis. The information available from the dataset shows the final transaction price and does not allow for accurate estimation of the economic surplus created by the avoidance of double taxation. However, estimates of this surplus might be made based on the difference between target firm equity, which is provided on a book (non-tax) basis, and the transaction price. This additional step of estimating the economic surplus may lead to a deeper understanding of entity choice implications. 
Considering allocation of the economic surplus is important even though this analysis presented strong evidence in support of the influence of entity choice and market participant type on firm value. For example, consider two otherwise identical companies, one a $\mathrm{C}$ corporation and one a passthrough entity that are acquired at the same price. This may occur if the acquiring firm, perhaps through superior negotiation skills, reaps all the benefits of avoiding double taxation by demanding the same price regardless of entity type. This scenario could interact in an important way with whether the acquiring firm is publicly traded or not since public buyers are presumably better negotiators and target a select group of firms for acquisition. If this were the case, no effect would be identified by the regression analysis.

However, double taxation could still be a strong disincentive for business growth because the seller is not receiving a pricing premium to compensate for losses due to double taxation. An alternative possibility is that the seller reaps the entire benefit of the economic surplus, in which case the price difference between $\mathrm{C}$ corporations and passthrough entities would be proportional to the tax benefit. While this is a possibility, it is much more likely that each of the parties to the transaction reap some of the benefit of the tax savings from the passthrough entity form. In this intermediate case, the results of the regression analysis likely understate the effect to the extent the economic surplus is appropriated by the acquiring firm. In any case, considering the implications of double tax and value appropriation make it clear that the results found in this study are likely understated.

As a robustness check, regressions were run on post December 31, 2017 data. As discussed above, business transactions after December 31, 2017 were eliminated due to the sweeping tax changes taking effect on January 1, 2018 (TCJA 2017). This tax act reduced C corporation tax to a flat 21 percent and, at the same time, provided a reduction to the individual income tax rates and a $20 \%$ deduction for qualifying business income received from a passthrough entity. Data for 1,570 sale transactions that occurred after December 31, 2017 (193 C corporations and 1,377 passthrough entities) were subsequently analyzed. Of these sales, 1,426 were structured as asset transactions with the remaining 144 structured as stock sales. Although this is a much smaller sample size, it was expected that analysis would demonstrate that as tax rates fall, the influence of tax on firm value and market participant type would decrease. Rerunning the regressions shown in Table 7 on this post December 31, 2017 dataset produced results supporting this theory. C corporation versus passthrough entity influence on firm value was significant at the $5 \%$ level $(p$ $<.05)$ for transactions structured as stock sales as opposed to the pre-2018 sale transactions with $p<.001$ (Table 7). No significant results were found for asset sales or for all transactions (stock and asset sales combined). Market participant type continued to show highly significant influence for all transactions and for sales structured as stock sales, but no significant results were found for asset sales. Interactions tested in Table 7 also, for the most part, were not significant other than Public x Ln_Sales, which was highly significant in the all transactions and stock sales models. Thus, the reduced significance of the post-2017 results suggests the important influence of taxation through entity choice and market participant type on firm value, especially under the current political climate where tax rates for corporations and individuals are expected to increase. However, since reduced significance could be, at least in part, attributable to the reduced statistical power associated with a smaller sample size, additional research in this area is required. Future changes in tax rates are likely to provide fertile ground for revisiting these research questions.

This research is an important next step in understanding closely held business organizations. The results of this study demonstrate that the firm value of closely held business organizations is associated with both entity selection and market participant type. 


\section{REFERENCES}

Aguinis, H. (2004). Regression Analysis for Categorial Moderators. New York, NY: Gilford.

Assidi, S., Aliani, K., \& Omri, M. (2016). Tax optimization and the firm's value: Evidence from the Tunisian context. Borsa Istanbul Review, 16(3), 177-184.

Ayers, B., Lefanowicz, C., \& Robinson, J. (2003). Shareholder taxes in acquisition premiums: The effect of capital gains taxation. The Journal of Finance, 58(6), 2783-2801.

Bargeron, L., Schlingemann, F., Stulz, R., \& Zutter, C. (2008). Why Do Private Acquirers Pay So Little Compared to Public Acquirers? Journal of Financial Economics, 89(3), 375-390.

Blair, E., \& Marcum, T. (2015). Heed Our Advice: Exploring How Professionals Guide Small Business Owners in Start-Up Entity Choice. Journal of Small Business Management, 53(1), 249-65.

Blair, E., Marcum, T., \& Fry, F. (2009). The disproportionate costs of forming LLCs vs. Corporations: The impact on small firm liability protection. Journal of Small Business Strategy, 20(2), 23-41.

Bryant-Kutcher, L.A., Guenther, D.A., \& Jackson, M. (2012). How Do Cross-Country Differences in Corporate Tax Rates Affect Firm Value? The Journal of the American Taxation Association, 34(2), 1-17.

Clark, M., \& Saade, R. (2011). The role of small business in economic development of the United States: From the end of the Korean War (1953) to the present. Available at SSRN 1803161.

Cloyd, C., Mills, L., \& Weaver, C. (2003). Firm valuation effects of the expatriation of U.S. corporations to tax-haven countries. Journal of the American Taxation Association, 25(s-1), 87-109.

Covrig, V., \& McConaughy, D. (2015). Public versus private market participants and the prices paid for private companies. Journal of Business Valuation and Economic Loss Analysis, 10(1), 77-97.

DeCelles, M., \& Wichmann, H. (1986). The impact of changing tax laws on the subchapter S corporation. Journal of Small Business Management, 24(3), 54-62.

DeChellis, A., Young, P., Van Grevenhof, J., \& Groat, D. (2017). Tax Planning for High Income Individuals (14th Edition). Fort Worth, Tx: Thomson Tax \& Accounting.

Demere, P., \& Gramlich, J. (2018). The Value of International Income Shifting to US Multinational Firms: Evidence from a New Income Shifting Identification Strategy. Available at SSRN 2826132.

Denis, D., \& Sarin, A. (2002). Taxes and the relative valuation of S corporations and C corporations. Journal of Applied Finance, 12(2), 5-14.

Desai, M.A., \& Dharmapala, D. (2009). Corporate tax avoidance and firm value. The Review of Economics and Statistics, 91(3), 537-546.

Dhaliwal, D.S., Erickson, M.M., \& Heitzman, S. (2004). The effect of seller income taxes on acquisition price: Evidence from purchases of taxable and tax-exempt hospitals. Journal of the American Taxation Association, 26(2), 1-21.

DiGabriele, J. (2008). The moderating effects of acquisition premiums in private corporations: An empirical investigation of relative $\mathrm{S}$ Corporation and $\mathrm{C}$ corporation valuations. Accounting Horizons, 22(4), 415-424.

DiGabriele, J. (2012). The moderating valuation effects of the organizational form of flow through entities. Journal of Business Valuation and Economic Loss Analysis, 7(1). doi:10.1515/19329156.1114

Dyer, L., \& Ross, C. (2007). Advising the small business client. International Small Business Journal, 25(2), 130-151.

Erickson, M., \& Wang, S. (2000). The effect of transaction structure on price: Evidence from subsidiary sales. Journal of Accounting and Economics, pp. 3059-97.

Erickson, M., \& Wang, S. (2007). Tax benefits as a source of merger premiums in acquisitions of private corporations. The Accounting Review, 82(2), 359-387.

Fama, E., \& French, K. (1997). Industry Costs of Equity. Journal of Financial Economics, 43, 153-93.

Granata, D., \& Chirico, F. (2010). Measures of Value in Acquisitions: Family Versus Nonfamily Firms. Family Business Review, 23(4), 341-354.

114 Journal of Applied Business and Economics Vol. 23(6) 2021 
Ilaboya, O., Izevbekhai, M., \& Ohiokha, F. (2016). Tax Planning and Firm Value: A Review of Literature. Business and Management Research, 5(2).

Jaccard, J., \& Turrisi, R. (2003). Interaction Effects in Multiple Regression. Thousand Oaks, CA: Sage.

Kimberly, J. (1979). Issues in the creation of organizations: Initiation, innovation, and institutionalization. Academy of Management Journal, 22(3), 437-457.

Pratt, S., Reilly, R., \& Schweihs, R. (2000). Valuing a business: the analysis and appraisal of closely held companies. NY: McGraw Hill

Slee, R.T. (2005). Public and Private Capital Markets Are Not Substitutes. Business Appraisal Practice, 29.

Swenson, C. (1999, June 7). Increasing stock market value by reducing effective tax rates. Tax Notes, pp. $1503-1505$.

U.S. House of Representatives. (2017). The Tax Cuts and Jobs Act. Public Law 115-97 [H.R. 1]. Washington, D.C.: Government Printing Office.

U.S. Small Business Administration Office of Advocacy. (2018). What's New with Small Business? Retrieved March 2019, from https://www.sba.gov/sites/default/files/Whats-New-With-SmallBusiness-2018.pdf

Yale, C., \& Forsythe, A. (1976). Winsorized regression. Technometrics, 18(3), 291-300. 